
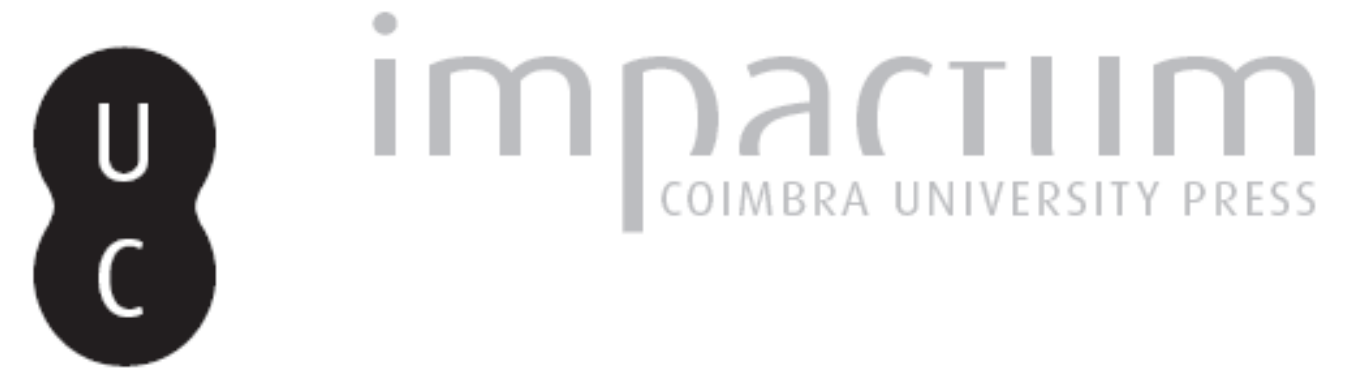

\title{
Economics in the crisis
}

\author{
Autor(es): Krugman, Paul
}

Publicado por: Faculdade de Economia da Universidade de Coimbra

URL persistente:

URI:http://hdl.handle.net/10316.2/25238

DOI:

DOI:http://dx.doi.org/10.14195/2183-203X_37_3

Accessed : $\quad$ 26-Apr-2023 10:58:41

A navegação consulta e descarregamento dos títulos inseridos nas Bibliotecas Digitais UC Digitalis, UC Pombalina e UC Impactum, pressupõem a aceitação plena e sem reservas dos Termos e Condições de Uso destas Bibliotecas Digitais, disponíveis em https://digitalis.uc.pt/pt-pt/termos.

Conforme exposto nos referidos Termos e Condições de Uso, o descarregamento de títulos de acesso restrito requer uma licença válida de autorização devendo o utilizador aceder ao(s) documento(s) a partir de um endereço de IP da instituição detentora da supramencionada licença.

Ao utilizador é apenas permitido o descarregamento para uso pessoal, pelo que o emprego do(s) título(s) descarregado(s) para outro fim, designadamente comercial, carece de autorização do respetivo autor ou editor da obra.

Na medida em que todas as obras da UC Digitalis se encontram protegidas pelo Código do Direito de Autor e Direitos Conexos e demais legislação aplicável, toda a cópia, parcial ou total, deste documento, nos casos em que é legalmente admitida, deverá conter ou fazer-se acompanhar por este aviso.

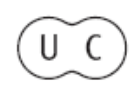




\section{N ○ TASEC O N O MICAS}

$\Delta$

\section{PAUL KRUGMAN'S TRIPLE DOCTORATE}

JORGE BRAGA DE MACEDO

PAUL KRUGMAN JOSÉ SILVA LOPES

ANDRÉ CHAîNEAU

ADÃO CARVALHO

ELSA DE MORAIS SARMENTO/

VANDA DORES /

GUIDA NOGUEIRA

ECONOMISTA MILITANTE

ECONOMICS IN THE CRISIS

COMMENT

LA MONNAIE ET SẸS SINGULARITÉS

FINANCIAMENTO PÚBLICO Ȧ I\&D EMPRESARIAL EM PORTUGAL

A COMPETITIVIDADE E A DIVERSIFICAC,ÃO DA FILEIRA FLORESTAL PORTUGUESA

$\Leftrightarrow$

$\Leftrightarrow$

$(-)$

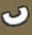

(2)

$\theta$

a

$\theta$ 37

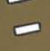
क

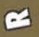
iv 


\section{Economics in the Crisis}

\section{Paul Krugman}

To say the obvious: we're now in the fourth year of a truly nightmarish economic crisis. I like to think that I was more prepared than most for the possibility that such a thing might happen; developments in Asia in the late 1990s badly shook my faith in the widely accepted proposition that events like those of the 1930s could never happen again. But even pessimists like me, even those who realized that the age of bank runs and liquidity traps was not yet over, failed to realize how bad a crisis was waiting to happen - and how grossly inadequate the policy response would be when it did happen.

And the inadequacy of policy is something that should bother economists greatly - indeed, it should make them ashamed of their profession, which is certainly how I feel. For times of crisis are when economists are most needed. If they cannot get their advice accepted in the clinch or, worse yet, if they have no useful advice to offer - the whole enterprise of economic scholarship has failed in its most essential duty.

And that is, of course, what has just happened.

In what follows I will talk first about the general role of economics in times of crisis. Then I'll turn to the specifics of the role economics should have been playing these past few years, and the reasons why it has for the most part not played this role. At the end I'll talk about what might make things better the next time around.

\section{Crises and useful economics}

Let me start with a paradox: times of economic disturbance and disorder, of crisis and chaos, are times when economic analysis is especially likely to be wrong. Yet such times are also when economics is most useful.

Why the paradox? Well, first of all, consider what economics can contribute in calm times.

The answer, l'd submit, is surprisingly little. OK, economists can explain why the system works the way it does, and offer useful advice about reforms that would make it better; there's always use for good microeconomics.

But if you're trying to make predictions, economists won't have much to contribute. Take the case of exchange rates, one of my original home areas of research. In ordinary times, it's very, very hard for structural models to beat a random walk - that is, models based on an attempt to track the forces moving the exchange rate, such as changes in prices and changes in monetary policy, are barely if at all better than the simple guess that tomorrow's exchange rate will be the same as today's. And it's even harder to beat an experienced trader, who has been through many fluctuations and has developed both useful rules of thumb about price patterns and a strong intuitive sense of what comes next.

Economic modelers may be better placed to engage in policy analysis. But even here, experienced practical hands may have the better advice to offer; they know from experience what will soothe the markets, what will rile them, and as long as events remain within the range of their experience, this informal understanding may trump the inevitably simplified and stylized analysis of those who know the world through equations and diagrams.

But now let there be a severe disruption that pushes the economy into terrain experienced practical men have never seen - say, an environment in which credit markets collapse, or shortterm interest rates on assets considered safe are pushed all the way to zero. Because there are large and normally unforeseen disruptions, the sheer unpredictability of events will mean many bad economic forecasts, so if you ask how nearly right economists are in their ability to predict events, they will seem to be doing very badly compared with calmer times. But the question you 
should ask is how economists are doing compared with those who use other ways to understand the world, and in particular how they are doing compared with sober, serious, experienced men in suits. And it is precisely in disturbed times that economists can and sometimes do offer dramatically better predictions and policy judgments than what we normally consider wise men.

Take, for example, the relationship between deficits and interest rates. It's not an example chosen at random, of course; I believe that it gets to the heart both of the nature of the crisis we're in and the terrible failure of economists - plus, not incidentally, it happens to be something I personally got right. More about that shortly. But for now, let's just focus on what we should have known.

Most practical men, confronted with the prospect of unprecedented deficits in the United States, the UK, and elsewhere, extrapolated from their usual experience, in which increased borrowing drives up interest rates. And so there were widespread predictions of sharp rate rises. Most famously, perhaps, Morgan Stanley predicted in late 2009 that interest rates on 10-year US bonds, then around 3.5 percent, would shoot up to 5.5 percent in 2010; in early 2011 Pimco's legendary head, Bill Gross - who had correctly predicted low rates in 2010,predicted a rate spike by the summer. And in each case these views were very widely held.

But economists who knew basic macroeconomic theory - specifically, the IS-LM model, which was John Hicks's interpretation of John Maynard Keynes, and at least used to be in the toolkit of every practicing macroeconomist - had a very different take. By late 2008 the United States and other advanced nations were up against the zero lower bound; that is, central banks had cut rates as far as they could, yet their economies remained deeply depressed. And under those conditions it was straightforward to see that deficit spending would not, in fact, raise rates, as long as the spending wasn't enough to bring the economy back near full employment. It wasn't that economists had a lot of experience with such situations (although Japan had been in a similar position since the mid-1990s). It was, rather, that economists had special tools, in the form of models, that allowed them to make useful analyses and predictions even in conditions very far from normal experience.

And those who knew IS-LM and used it - those who understood what a liquidity trap means - got it right, while those with lots of real-world experience were wrong. Morgan Stanley eventually apologized to its investors, as rates not only stayed low but dropped; so, later, did Gross. As I speak, deficits remain near historic highs - and interest rates remain near historic lows.

Crises, then, are times when economics and economists can and should really prove their worth. And l'd like to say that some of my friends and colleagues did; maybe some of them will say that I did OK, too. But one can't say that of the profession as a whole. On the contrary, all too many of us had rejected the very kinds of analysis that were to prove so useful. And more than that, all too many actively opposed the policy measures the crisis called for.

Actually, let me talk a bit more about the failures of the economics profession in this crisis.

What should economists have known?

The most common accusation against economists in this crisis is that they failed because they didn't see it coming. Even the Queen of England has demanded that economists explain their failure to predict the crisis. But I would actually defend my colleagues against assertions that this predictive lapse was, in and of itself, all that much of a failure.

To take the most absurd case, nobody could realistically have demanded that the economics profession predict that Lehman Brothers would go down on September 15, 2008, and take much of the world economy with it. In fact, it's not reasonable to criticize economists for failing to get the year of the crisis right, or any of the specifics of how it played out, all of which probably depended on detailed contingencies and just plain accident.

What you can criticize economists for - and indeed, what I sometimes berate myself for - is failing even to see that something like this crisis was a fairly likely event. In retrospect, it 
shouldn't have been hard to notice the rise of shadow banking, banking that is carried out by non-depository institutions such as investment banks financing themselves through repo. And it shouldn't have been hard to realize that an institution using overnight borrowing to invest in longer-term and somewhat illiquid assets was inherently vulnerable to something functionally equivalent to a classic bank run - and, furthermore, that the institutions doing this were neither backed by deposit insurance nor effectively regulated. Economists, of all people, should have been on guard for the fallacy of misplaced concreteness, should have realized that not everything that functions like a bank and creates bank-type systemic risks looks like a traditional bank, a big marble building with rows of tellers.

And I plead guilty to falling into that fallacy. I was vaguely aware of the existence of a growing sector of financial institutions that didn't look like conventional banks, and weren't regulated like conventional banks, but engaged in bank-like activities. Yet I gave no thought to the systemic risks.

Even more broadly, economists should have been aware of the dangers of leverage. This was hardly a new concern. Back in 1933 - yes, 1933 - Irving Fisher published his classic paper on debt deflation, that is, on the way high levels of debt create the possibility of a self-reinforcing downward spiral. And the paper remains astonishingly relevant; aside from a few archaisms of style it could have been written from today's headlines. So remembering Fisher all by itself should have been enough to rouse at least a few worries as household debt rose dramatically relative to income, not just in America, but in a number of European nations too.

Again, I plead guilty to negligence. I had especially little excuse for being oblivious to these dangers given that I had actually laid great stress on balance-sheet factors in causing financial crises in emerging market. True, those crises had a lot to do with currency mismatch - basically, private debt in other countries' currencies, so that a speculative attack on a currency could quickly translate into a crippling collapse of domestic demand. But I and others should have seen that this was only one possible channel for balance-sheet crises, that plunges in housing prices or for that matter income could have the same effect.

So economists fell down on the job by not seeing what were in retrospect clear warning signs that the kind of crisis that struck in 2008 was both possible and becoming increasingly likely.

Yet I would submit that these predictive failures were venial sins compared with the much more important failure to speak with anything like a unified voice on how to respond to the crisis when it came.

\section{Depression economics and how it was lost}

Suppose that something like the crisis of 2008 had struck, say, 40 years ago. At that point, I believe, there would have been widespread agreement on the part of economists about what to do. Everyone in the profession knew IS-LM analysis; everyone understood the case for expansionary monetary policy to fight recessions when it was available, and at least understood the argument that there are times when conventional monetary policy is not available and fiscal policy may be the best tool at hand.

By the time the crisis actually did strike, however, all too many of my colleagues had either rejected or forgotten the analysis they needed. And as a result there was a cacophony of voices when we needed a chorus, intellectual fog at the very moment when we desperately needed clarity of vision.

How did that happen? There was, of course, a deep divide within macroeconomics about the right kind of model, and I believe that one side of that divide got it very wrong (and I am, of course, right in that view!). But that is the sort of thing that happens in any field, and the principle that I personally am always right isn't a good basis for intellectual inquiry. What was wrong, instead, were three consequences of that intellectual divide that reflect very badly on the profession. First, one side of the divide became intellectually insular in a way that proved disastrous in the crisis. Second, much of the profession reacted to the dispute by running away 


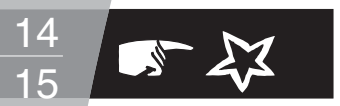

from the whole issue of slumps and what to do about them, again crippling the response to crisis. Finally, even the «right» side of the divide - that is, my side - let itself be bullied into a style of analysis that was inherently biased against any kind of readiness for crisis.

\section{Macroeconomics: What went wrong?}

I assume that most of those hearing or reading this speech at all closely are aware of the great divide that emerged in macroeconomics in the 1970s. For those who aren't familiar with the story: in the 1930s Keynesian economics emerged as a response to depression, and by the 1950s it had come to dominate the field. There was, however, an undercurrent of dissatisfaction with that style of modeling, not so much because it fell short empirically as because it seemed intellectually incomplete. In «normal» economics we assume that prices rise or fall to match supply with demand. In Keynesian macroeconomics, however, one simply assumes that wages and perhaps prices too don't fall in the face of high unemployment, or at least fall only slowly.

Why make this assumption? Well, because it's what we see in reality - as confirmed once again by the experience of peripheral European countries, Portugal included, where wage declines have so far been modest even in the face of very high unemployment. But that's an unsatisfying answer, and it was only natural that economists would try to find some deeper explanation.

The trouble is that finding that deeper explanation is hard. Keynes offered some plausible speculations that were as much sociological and psychological as purely economic - which is not to say that there's anything wrong with invoking such factors. Modern «New Keynesians» have come up with stories in terms of the cost of changing prices, the desire of many firms to attract quality workers by paying a premium, and more. But one has to admit that it's all pretty ad hoc; it's more a matter of offering excuses, or if you prefer, possible rationales, for an empirical observation that we probably wouldn't have predicted if we didn't know it was there.

This, understandably, wasn't satisfying to many economists. So there developed an alternative school of thought, which basically argued that the apparent «stickiness» of wages and prices in the face of unemployment was an optical illusion. Initially the story ran in terms of imperfect information; later it became a story about «real» shocks, in which unemployment was actually voluntary; that the real business cycle approach.

And so we got the division of macroeconomics. On one side there was «saltwater» economics people, who in America tended to be in coastal universities, who continued to view Keynes as broadly right, even though they couldn't offer a rigorous justification for some of their assumptions. On the other side was «freshwater» - people who tended to be in inland US universities, and who went for logically complete models even if they seemed very much at odds with lived experience.

Obviously I don't believe any of the freshwater stories, and indeed find them wildly implausible. But economists will have different ideas, and it's OK if some of them are ones I or others dislike.

What's not OK is what actually happened, which is that freshwater economics became a kind of cult, ignoring and ridiculing any ideas that didn't fit its paradigm. This started very early; by 1980 Robert Lucas, one of the founders of the school, wrote approvingly of how people would giggle and whisper when facing a Keynesian. What's remarkable about that is that this was all based on the presumption that freshwater logic would provide a plausible, workable alternative to Keynes a presumption that was not borne out by anything that had happened in the 1970s. And in fact it never happened: over time, freshwater economics kept failing the test of empirical validity, and responded by downgrading the importance of evidence.

This was, by the way, not a symmetric story: saltwater economists continued to read Lucas and his successors. So only one side of the divide shut itself off from opposing views.

And this inward turning had what can now be seen as a fateful consequence: freshwater macro, basically something like half or more the macroeconomics field, stopped teaching not only new Keynesian research but the past as well. And what that meant was that when crisis struck, we 
had half a generation of economists who not only had no model that could make sense of the crisis, but who blithely reproduced classic errors of the past. Keynes spent a good part of his magnum opus, The General Theory of Employment, Interest, and Money, refuting Say's Law the proposition that income must be spent, so that shortfalls of demand are impossible, and government spending in particular cannot add to demand. Yet in 2008 and 2009 we had wellknown professors from Chicago and elsewhere opposing stimulus because ... income must be spent, so government spending cannot increase demand. Intellectually, much of the profession had unknowingly regressed 75 years.

Worse yet, the consequences were not limited to the acolytes of freshwater economics. Quite a few economists responded to the bitter warfare between schools of thought by running away from business cycle issues in general. I know whereof I speak: when Robin Wells and I began writing our principles of economics textbook, the general view was that you should focus on long-run growth, and relegate things like recessions and recoveries to a brief section at the end. Why? Because focusing on the long run was safer, less likely to get the committees that choose textbooks riled up.

The problem, of course, is exactly the one Keynes himself diagnosed in his most famous quote:

«But this long run is a misleading guide to current affairs. In the long run we are all dead. Economists set themselves too easy, too useless a task if in tempestuous seasons they can only tell us that when the storm is long past the ocean is flat again.»

Finally, all was not well even in saltwater economics.

Even though saltwater economists had too much reality sense to accept the notion that unemployment is an illusion and recessions are voluntary, indeed optimal, they were not immune to the push for more rigor and more math. You might say that they suffered from rigor envy. And so New Keynesian models tried to have as few deviations from perfect markets as possible, and tried to embed their analysis in a framework where everyone knew what was going on and behaved optimally except for a few ad hoc constraints. The result was DSGE - dynamic stochastic general equilibrium - models, which looked a lot like real business cycle models, except for the assumed wage/price stickiness.

So what's wrong with that? Well, DSGE models have three aspects that make them unsuited to times like these. First, they're unwieldy; you can't easily sketch out your argument on a piece of paper, and you can't easily translate it into ordinary language to explain it to a politician. Second, they normally assume that the data we see come from a regular process of random shocks, with strong incentives for the modeler to assume that the shocks are more or less normal, not involving large, low probability events - which leaves you unready for the Big One when it happens. Finally, the desire to make the things tractable tends to favor linearity, or at least models that can be done in terms of linear approximations; again, that's not a modeling style that leaves you ready to deal with sudden financial crisis, which may involve multiple equilibria and at the very least involves regime change in which the effects of a given policy or shock may suddenly become quite different.

What we really needed, l'd submit, was a large number of economists ready and willing to go for good first approximations - quick and dirty but intellectually sophisticated approaches that would let them respond to a radically changed economic environment. Good old-fashioned IS-LM fits the bill, and as I see it the economists who did best in this crisis began with IS-LM, then backed it up later with simplified versions of New Keynesian analysis. But knowledge of IS-LM has become surprisingly rare, and comfort with it - appreciation of its virtues as well as its vices, and understanding of just how sophisticated it really is in some ways - has become even rarer.

And this has had terrible consequences. 


\section{From analysis (or lack thereof) to policy}

In the years after 1980, and even more so, the years after 2000, the foundations for crisis were laid. The banking system became, de facto, largely unregulated and unsecured. Leverage rose, both fueling and fueled by housing bubbles (and, in Europe, the false confidence fostered by the creation of the euro). The conditions for disaster became ever better; and the disaster came.

Now what? The answer should have been simple, and backed by an overwhelming consensus. The immediate problem was a huge shortfall of demand, as the private sector moved from large financial deficit to large financial surplus. To avoid terrible effects on output and employment effects that would only magnify the problems of excess leverage - we needed not just a rescue of the financial system but also strong government action to support demand while the wreckage was cleared.

What kind of action? There was and is a case for large-scale unconventional monetary policy, which in a zero-bound economy has to work largely through inflation expectations. But the more proximate tool, with the greatest known effectiveness, was fiscal policy, especially increased government purchases of goods and services.

Anyone who knew the IS-LM model understood that. But too much of the economic profession had lost the hard-won understanding of earlier generations. So instead of a common call for action, we got acrimonious argument, with quite a few economists essentially acting as spoilers, undermining the credibility of those trying to get governments to do the right thing. And as I said, to a remarkable extent the «learned» arguments against government action were actually repeating fallacies like Say's Law and the Treasury View that had been thoroughly refuted in the 1930s.

Should we be surprised, then, that economic policy makers, after responding fairly effectively to the banking crisis, proceeded to lose the thread?

What happened, in fact, was that to a large extent policy makers ended up going for economic doctrines that made them feel comfortable, that corresponded to the prejudices of men not versed in economics. Thus, it's normal to think of the economy as a whole as being like a family, which must tighten its belt in hard times; it's also completely wrong. But lacking any clear message from the economists about how and why this is wrong, it became the common standard of discussion in America, where both Republicans and, alas, President Obama became very fond of the statement that the government should tighten its belt because families were tightening theirs.

It's also normal to think of economics as a morality play, a tale of sin and redemption, in which countries must suffer for their past excesses. Again, this normal reaction is wrong, or at least mostly wrong -mass unemployment does nothing to help pay off debt. But absent clear guidance from the people who are supposed to explain that economics is not, in fact, a morality play, moralizing became the core of economic policy thinking in Germany, and hence played a huge role in European policy more generally.

Finally, government officials who hang out with businessmen - and almost all of them do naturally tend to be attracted to views that put business confidence at the heart of the economic problem. Sure enough, belief that one should slash spending even in a depressed economy, and that this would actually promote growth because it would have positive effects on confidence, spread like wildfire in 2010 . There were some economic studies used to justify the doctrine of expansionary austerity - studies that quickly collapsed under scrutiny. But really, the studies became popular because they suited the prejudices of politicians, prejudices that would have been totally familiar to Herbert Hoover or Heinrich Brüning.

And so our response to the crisis has been utterly inadequate. 


\section{The failure of economics}

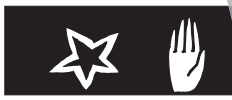

The best you can say about economic policy in this slump is that we have for the most part avoided a full repeat of the Great Depression. I say «for the most part» because we actually are seeing a Depression-level slump in Greece, and very bad slumps elsewhere in the European periphery. Still, the overall downturn hasn't been a full 1930s replay. But all of that, I think, can be attributed to the financial rescue of 2008-2009 and automatic stabilizers. Deliberate policy to offset the crash in private spending has been largely absent.

And I blame economists, who were incoherent in our hour of need. Far from contributing useful guidance, many members of my profession threw up dust, fostered confusion, and actually degraded the quality of the discussion. And this mattered. The political scientist Henry Farrell has carefully studied policy responses in the crisis, and has found that the near-consensus of economists that the banks must be rescued, and the semi-consensus in favor of stimulus in the initial months (mainly because the freshwater economists were caught by surprise, and took time to mobilize) was crucial in driving initial policy. The profession's descent into uninformed quarreling undid all that, and left us where we are today.

And this is a terrible thing for those who want to think of economics as useful. This kind of situation is what we're here for. In normal times, when things are going pretty well, the world can function reasonably well without professional economic advice. It's in times of crisis, when practical experience suddenly proves useless and events are beyond anyone's normal experience, that we need professors with their models to light the path forward. And when the moment came, we failed. 